\title{
Toba Batak House of Huta Bagasan in Jangga Dolog Village
}

\section{Ruma Batak Toba di Hutan Bagasan Desa JangGa Dolok}

\author{
M. Maria Sudarwani ${ }^{1 *}$, Iwan Priyoga ${ }^{2}$ \\ Program Studi Arsitektur, Fakultas Teknik, Universitas Pandanaran ${ }^{1 *}$ \\ maria.sudarwani@yahoo.co.id * \\ Program Studi Arsitektur, Fakultas Teknik, Universitas Pandanaran ${ }^{2}$
}

\begin{abstract}
Each region basically has a traditional house that has characteristics in accordance with the local wisdom of each region. Each traditional house will reflect the identity that grows in the area. The physical structure of the building of traditional houses in anthropology in different traditional societies will bring up building elements that are depicted in the form of ornaments as a symbol of meaning that has special meaning in the area. Symbolizing the building of a traditional society, the building elements have a special meaning that is recognized by the builders as an important element for building strength and stability. Research into the homes of a traditional society gives us some valuable views for the conception of housing. Likewise in the case study of a traditional house in Jangga Dolok Village, Lumbun Julu District, Toba Samosir Regency, North Sumatra Province. Majority of the people are Batak people. Batak Traditional Houses have a major influence in the spatial planning of the area. Besides that, the symbolization of houses living in Batak people cannot be separated from the influence of socio-cultural life and all aspects manifested in the symbolization of Batak Traditional Houses which have special meaning.
\end{abstract}

Keywords: Huta Bagasan, Jangga Dolok, Ruma Batak

\section{PENDAHULUAN}

Di langgam arsitektural dari suatu kawasan cenderung diadaptasi dengan lingkungan lokal dan menggunakan material setempat. Arsitektur tradisional Batak merupakan salah satu wujud jati diri masyarakat Batak yang memiliki cerminan nilai dan karakteristik yang unik serta merupakan sebuah warisan yang tidak ternilai. Ada enam kelompok warga Batak yang tinggal di daerah ini, yaitu 1) Toba Batak, 2) Karo Batak, 3) Pakpak and Dairi Batak, 4) Simalungun Batak, 5) Angkola and Sipirok Batak, 6) dan Mandailing Batak. Meskipun ada enam kelompok yang relatif berbeda letak geografisnya, mereka mempercayai mitos bahwa mereka adalah satu keturunan yang sama dari Raja Batak yang lahir di Desa Sianjur Mulamula di sebelah Barat Danau Toba
(Situmorang 2004; Siahaan 2005; Nainggolan 2012 dalam Hima \& Meisyara 2017).

Salah satu obyek yang menarik diamati adalah Rumah-Rumah adat di Huta Bagasan Desa Jangga Dolok yang merupakan sebuah desa yang berada di daerah lembah bukit Dolok Simanuk-manuk, Kelurahan Lumbun Julu, Kabupaten Toba Samosir, Provinsi Sumatera Utara. Huta Bagasan merupakan salah satu daerah permukiman pertama di Desa Jangga Dolok dan merupakan salah satu perkampungan tua dengan beberapa Ruma Batak yang sudah berusia 200 tahun serta merupakan desa adat yang masih dilestarikan. Desa ini berjarak $40 \mathrm{~km}$ dari Kota Balige. Peta Desa Jangga Dolok dapat dilihat pada Gambar 1. 


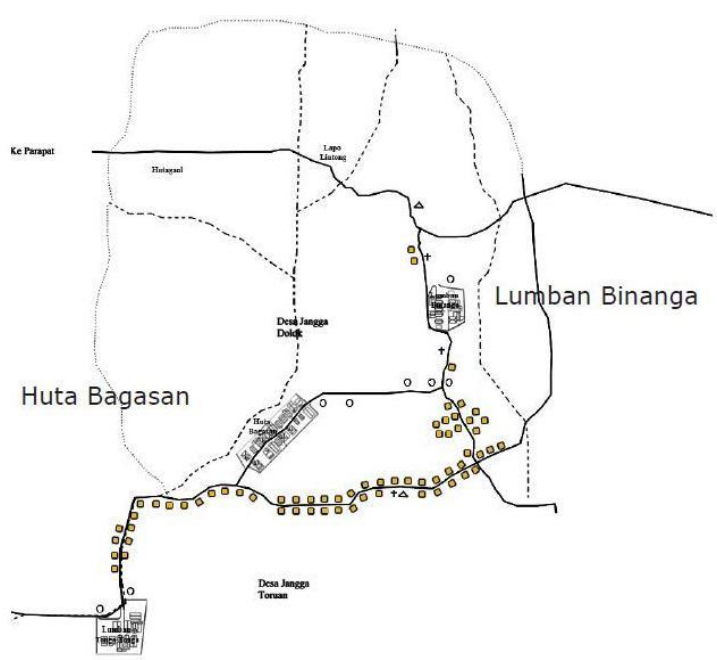

Gambar 1. Peta Desa Jangga Dolok (Hanan \& Meisyara, 2017)

Ruma Batak Toba merupakan salah satu Pusaka Indonesia yang turut berperan dalam menciptakan identitas Toba Samosir. Oleh karena itu merupakan tanggung jawab kita bersama untuk menjaganya dari kepunahan. Diperlukan adanya studi untuk mendapatkan pemahaman yang jelas mengenai elemenelemen yang timbul sebagai ekspresi Ruma Batak Toba. Di Huta Bagasan ada beberapa permasalahan yang akan dikaji lebih lanjut di dalam bahasan ini, yaitu elemen-elemen Rumah adat dan penggunaannya serta pengaruh kehidupan sosial budaya pada bentuk Ruma adat. Pembahasan dilakukan untuk mengkaji elemen-elemen yang ada pada Ruma Batak Toba di Huta Bagasan Desa Jangga Dolok yang memiliki keunikan dan keistimewaan serta adanya pengaruh kehidupan sosial budaya pada bentuk dan ornamen bangunan. Prinsip-prinsip teknis dalam membangun sebuah rumah pada dasarnya sama dalam semua suku bangsa, apabila yang dituntut adalah jawaban satu permintaan, yakni: dapat dipakai menurut kebutuhan pemakai. Sedangkan pada rumah di Tanah Batak, kita sudah menemukan suatu kelebihan, karena selain dapat digunakan, rumah itu mencahayakan nilai lebih, nilai pengangkatan jiwa manusia kepada yang lebih luhur. Dengan kata lain: selain unsur guna, kita menemukan dalam karya arsitektur manusia yang berkebudayaan: unsur citra (Mangunwijaya, 1995:19).

\section{METODE}

Pada penelitian ini metode yang dipergunakan adalah pendekatan rasionalistik dengan paradigma kualitatif. Pendekatan penelitian rasionalistik kualitatif ini sesuai dengan sifat masalah penelitian yaitu untuk mengungkap atau memahami Ruma Batak Toba di Huta Bagasan Desa Jangga Dolok berdasar landasan berpikir dan dialog pengetahuan. Untuk mengkaji arsitektur Ruma Batak Toba, terlebih dahulu ditetapkan komponen-komponen yang akan diteliti yaitu sebagai berikut: 1) Komponen Utama berupa Elemen Arsitektur Ruma adat di Huta Bagasan Desa Jangga Dolok, yang membentuk dan memberi ciri khas daerah tersebut, terdiri dari fenomena fisik yang berkaitan dengan hubungan antar bangunan dan selaras dengan teori bentuk dan massa bangunan (Shirvani, 1985) yang meliputi: atap, ornamen, fasade, warna; 2) Komponen Penunjang berupa Kebudayaan dan Kehidupan sosial budaya di Desa Jangga Dolok, terutama karakteristik sosial budaya yang menunjang terbentuknya bentuk Ruma adat.

Analisis data penelitian ini menggunakan analisis data kualitatif (analisis data verbal) yang disesuaikan dengan permasalahan dan tujuan yang telah ditetapkan, serta mencari esensi dengan mendudukkan kembali hasil penelitiannya pada grand concepts nya (Muhadjir, 1996).

\section{ANALISIS DAN INTERPRETASI}

Huta Bagasan Jangga Dolok merupakan sebuah desa yang berada di daerah lembah bukit Dolok Simanuk-manuk, Kecamatan Lumban Julu, Kabupaten Toba Samosir, Sumatera Utara.

\subsection{Sejarah Jangga Dolok}

Legenda Jangga Dolok dimulai dari cerita seorang penjelajah bernama Guru Pangajian Manurung yang berasal dari Sibisa memburu seekor burung Patia Raja yang memiliki kekuatan gaib sehingga sulit untuk ditemukan dan sulit mati. Dengan senjata ultop yang sakti, burung tersebut akhirnya bisa tumbang. Ternyata di dalam perut burung itu terdapat padi kemudian padi tersebut diambil untuk ditanamnya di daerah tersebut. Berawal dari situlah terjadinya permukiman pertama, yaitu Huta Bagasan. Sesudah itu muncul 
permukiman Lumban Binanga, Lumban Tonga-Tonga, dan Sosor (Katalog Rumah Asuh, 2018). Tragedi terbakarnya Ruma Batak di Lumban Binanga Jangga Dolok pada tahun 2016 menjadi kabar yang memprihatinkan mengingat sudah sangat langkanya para ahli atau seorang Pande yang bisa membangun ulang seratus persen Jabu Bolon. Reruntuhannya langsung dibuang dan dijauhkan dari desa oleh warga setempat karena diyakini dapat menghadirkan bala atau bencana. Tetapi tragedi tersebut menjadi titik balik perjuangan masyarakat Jangga Dolok untuk membangun kembali tradisi dan spiritualitas adat nenek moyang dan juga merupakan sebuah panggilan agar kita lebih peduli dengan budaya nenek moyang.

\subsection{Elemen Arsitektur}

Prinsip-prinsip teknis dalam membangun sebuah rumah pada dasarnya sama dalam semua suku bangsa, apabila yang dituntut adalah jawaban satu permintaan, yakni: dapat dipakai menurut kebutuhan pemakai. Tetapi dalam ruma batak kita sudah menemukan suatu kelebihan, karena selain dapat digunakan, rumah itu mencahayakan nilai lebih, nilai pengangkatan jiwa manusia kepada yang lebih luhur. Dengan kata lain: selain unsur guna, kita menemukan dalam karya arsitektur manusia yang berkebudayaan: unsur citra (Mangunwijaya, 1995). Dalam arsitektur Ruma Batak tampilan bangunan menunjukkan adanya persolekan bagian luar bangunan yang sangat menawan. Tampilan luar bangunan didominasi oleh tampilan wujud atap bangunan dengan bukulan (nok) yang menjulang ke arah gunung. Tampilan ini semakin dipermantap dengan ornamen dan dekorasi fasade yang bercorak tetumbuhan serta geometrisasinya, serta dengan menggunakan warna yang mencolok dan segar. Kecenderungan untuk mendominankan tampilan luar ini sejalan dengan pendayagunaan ruang terbuka di luar bangnan yang dijadikan kegiatan hidup sehari-hari (Prijotomo, 2018).

\subsubsection{Tata Letak dan Bentuk Denah}

Semua Rumah Batak berbentuk struktur rumah panggung dan memiliki langgam arsitektur yang sama meski fasade berbeda-beda. Dalam satu perkampungan ruma batak, depan setiap Ruma Batak selalu didirikan Sopo (lumbung padi). Ruang terbuka antara ruma dan sopo digunakan untuk banyak tujuan terutama untuk upacara ritual dan untuk bekerja. Tata letak perkampungan Batak Toba mengikuti pola berbanjar dua seperti yang diperlihatkan pada Gambar 2. Tata letak ruma berderet dengan ruma yang lain sedang di sisi depan berhadaphadapan terletak deretan sopo (lumbung padi) dari ruma tersebut. Deretan ruma Batak dapat dilihat pada Gambar 3.

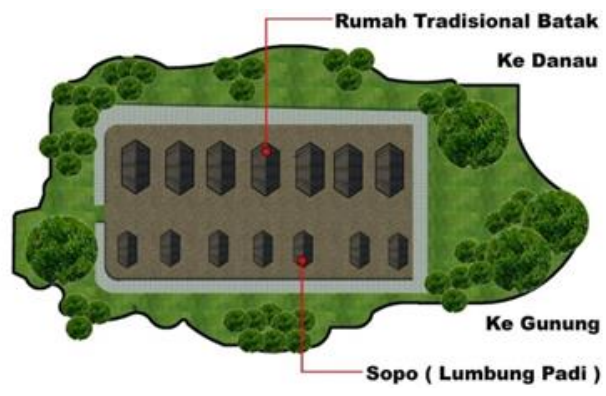

Gambar 2. Tata letak perkampungan Ruma Batak

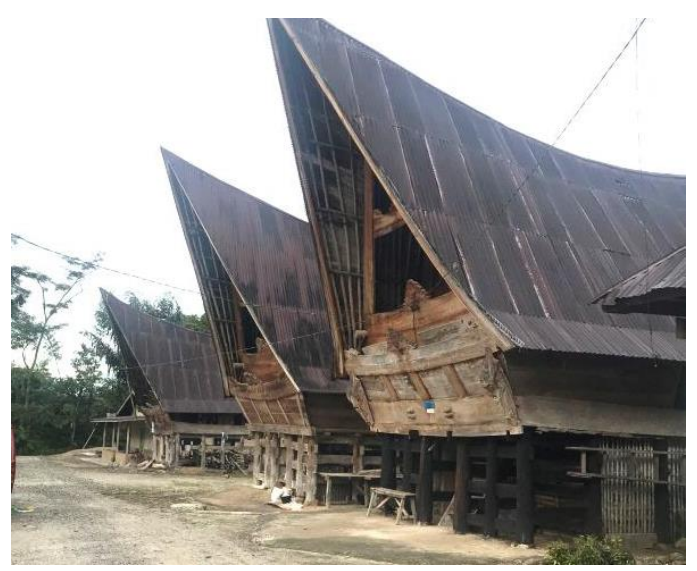

Gambar 3. Deretan ruma di Huta Bagasan

Orientasi bangunan yang cukup kuat selaras dengan lingkungan alam sekitarnya, yaitu gunung dan danau. Atap ruma batak didirikan dengan orientasi sumbu arah gunung dan danau dengan Bukulan bagian depan menghadap langsung ke gunung dan ke ruang terbuka (Hanan \& Wonorahardjo, 2012). Menurut tetua adat gunung bagi orang Batak merupakan lambang kekuatan alam yang dihormati sebagai arah orientasi ruma batak. Di marga tertentu bahkan ketinggian bukulan bagian depan yang menghadap langsung ke gunung dibuat lebih tinggi dari pada bukulan bagian belakang yang berorientasi ke danau. Sedangkan danau dipercaya memiliki kekuatan negatif, sehingga 
danau diposisikan sebagai orientasi rumah bagian belakang.

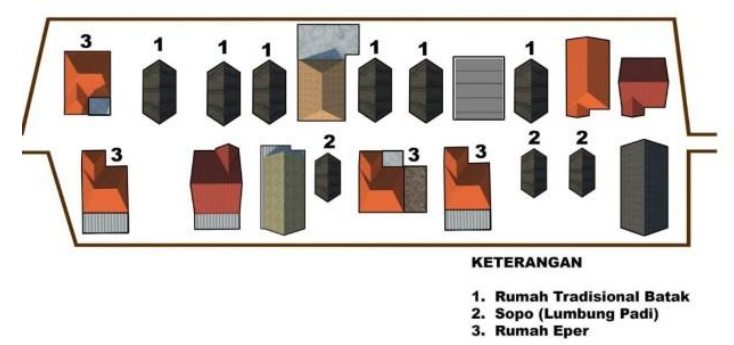

Gambar 4. Tapak perkampungan Huta Bagasan

Demikian pula di perkampungan Huta Bagasan Desa Jangga Dolok. Dari Gambar 4 Tapak Perkampungan Huta Bagasan terlihat bahwa Huta Bagasan yang merupakan perkampungan pertama di Desa Jangga Dolok masih menganut arah orientasi perkampungan dengan deretan rumah batak berada di sisi atas dengan tanda nomor 1, dan deretan sopo (lumbung padi) berhadap-hadapan dengan rumah tinggal dengan tanda nomor 2. Tetapi ada juga tipe rumah eper dengan tanda nomor 3 yang merupakan rumah vernakuler kampung setempat yang berbahan kayu dan juga rumah berbahan batu bata. Huta Bagasan dilengkapi dengan dua pintu masuk di sisi Utara dan Selatan huta.

Ukuran Denah Ruma Batak beragam, ukuran ideal yang sedang $5 \mathrm{~m} \times 8 \mathrm{~m}$, di Lumban Nabolon ukuran sampai dengan $8 \mathrm{~m} \times 14 \mathrm{~m}$. Ukuran ini juga mempengaruhi jumlah perletakan tiang penyangga rumah dari tiang modul 7 × 6, modul 9 × 8, dan lain-lain. Contoh denah ruma Batak dapat dilihat pada Gambar 5 . Tinggi Ruma Batak dari pondasi ke puncak atap (ulu paung) lebih kurang $13 \mathrm{~m}$, yang berbentuk rumah panggung dengan konstruksi berdiri di atas tiang-tiang yang diletakkan di atas batu pondasi (ojahan). Tiang-tiang rumah tersebut terdiri atas tiang-tiang panjang (basiha rea) dan tiang-tiang pendek (basiha pandak), berbentuk bulat dengan diameter lebih kurang 50-70 cm. Tiang-tiang muka dan belakang dihubungkan dengan empat baris papan tebal yang disebut dengan tustus parbarat atau pangaruhut ni banua (pengikat benua), sedangkan bagian atas tiang-tiangnya dihubungkan dengan balok ransang yang diikat dengan solang-solang. Atap yang tinggi merupakan unsur paling dominan dari bangunan Ruma Batak, dengan konstruksi atap yang terbuat dari kayu dan bambu serta penutup atapnya yang terbuat dari ijuk (Soeroto, 2002).

Ruma Batak merupakan mikro kosmos yang melambangkan makro kosmos yang terbagi atas tiga bagian atau tri tunggal banua, yaitu: kaki, badan, dan kepala. Banua toru (bawah bumi) untuk kaki rumah, banua tonga (dunia) untuk badan rumah, dan banua ginjang (singa dilangit) untuk atap rumah seperti terlihat pada Gambar 6.

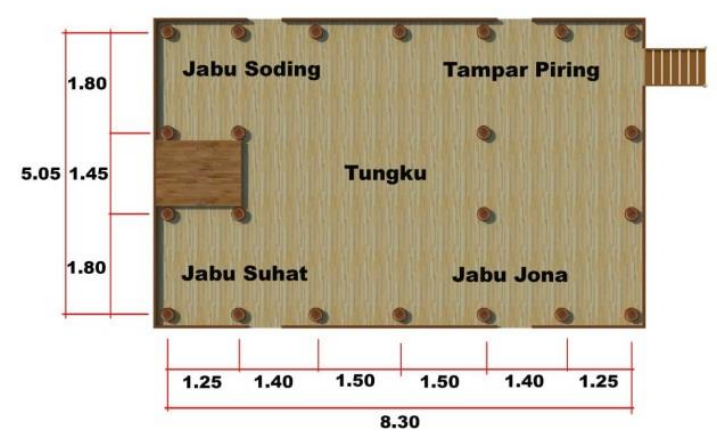

Gambar 5. Denah Ruma Batak

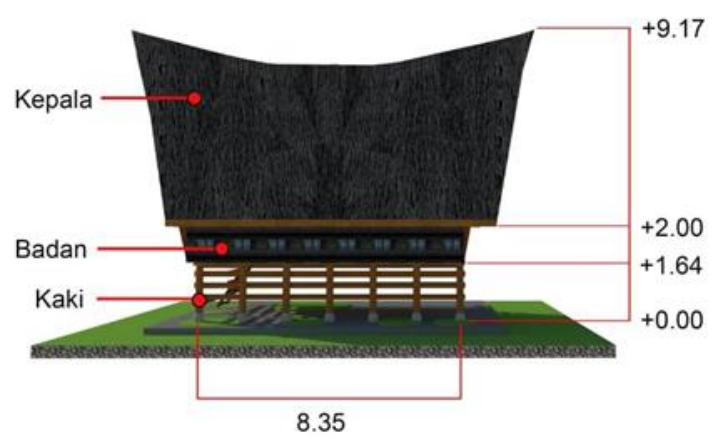

Gambar 6. Bentuk Tampak Samping Ruma Batak

\subsubsection{Tipologi dan Fasade Bangunan}

Tipologi Bangunan adat yang ada di Huta Bagasan Jangga Dolok antara lain: Tipologi Ruma (Rumah Tinggal) dan Sopo (Lumbung Padi). Ruma dan sopo dipisahkan oleh pelataran luas yang berfungsi sebagai ruang bersama warga Huta. Satu bangunan Ruma Batak dihuni oleh 1-4 keluarga, dengan ruang dalamnya terbagi menurut struktur adat Dalihan Notulu, yaitu merupakan sistem kekerabatan suku Batak Toba (Soeroto, 2002). Ruma biasanya ditinggali saat malam sampai pagi hari, sedang sopo biasanya untuk aktivitas siang sampai sore hari. Tipologi Rumah 
Tinggal yang lain yaitu Ruma Eper (dari kayu) dan ada juga rumah batu bata. Ruma Eper memiliki atap berbentuk limasan dengan canopy yang menonjol di bagian depan difungsikan untuk ruang tamu. Ada beberapa sebutan untuk Ruma Batak sesuai dengan kondisi rumahnya. Ruma batak dengan banyak hiasan ( $g$ orga) yang berukir dan bercat, disebut Ruma Gorga Sarimunggu atau Jabu Batara Guru. Sedangkan ruma batak yang tidak berukir dan tanpa cat disebut Jabu Ereng atau Jabu Batara Siang (Soeroto, 2002). Fasade Ruma Gorga Sarimunggu, Fasade Ruma Jabu Batara Siang, dan Ruma Eper dapat dilihat pada Gambar 7, 8 dan 9.

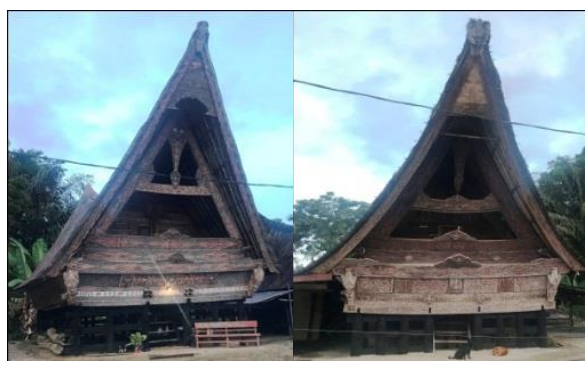

Gambar 7. Fasade Ruma Gorga Sarimunggu (Jabu Batara Guru)

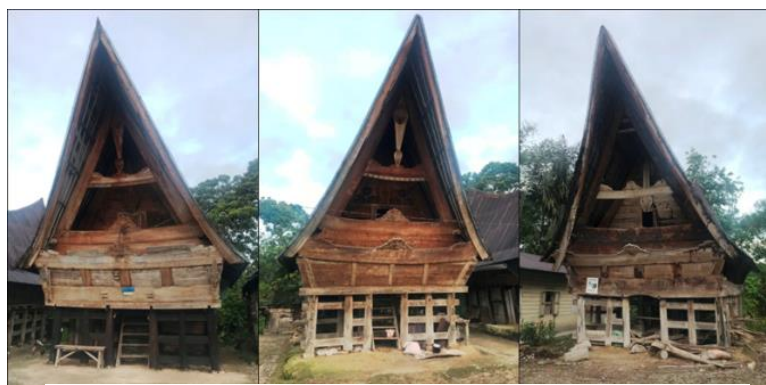

Gambar 8. Fasade Ruma Jabu Batara Siang

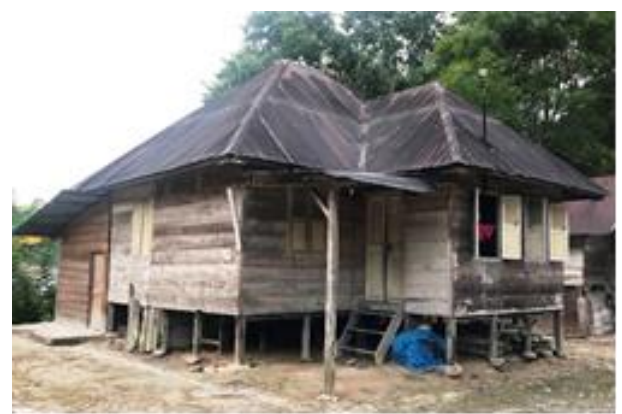

Gambar 9. Fasade Ruma Eper Huta Bagasan

Bangunan Sopo (lumbung) dibedakan menurut jumlah tiangnya, yaitu antara 4 sampai dengan 12 tiang. Sopo Siopat bertiang 4, Sopo Sionam bertiang 6, Sopo Siualu bertiang 8 dan Sopo
Belon bertiang 12. Sopo juga merupakan bangunan berbentuk bangunan panggung yang melambangkan tri-tunggal banua, dengan pembagian fungsi: ruang bawah panggung bangunan Sopo untuk ternak, bagian tengah tempat menenun dan bersantai, sedangkan bagian atas untuk tempat menyimpan padi (Soeroto, 2002). Fasade bangunan Sopo bisa dilihat pada Gambar 10.

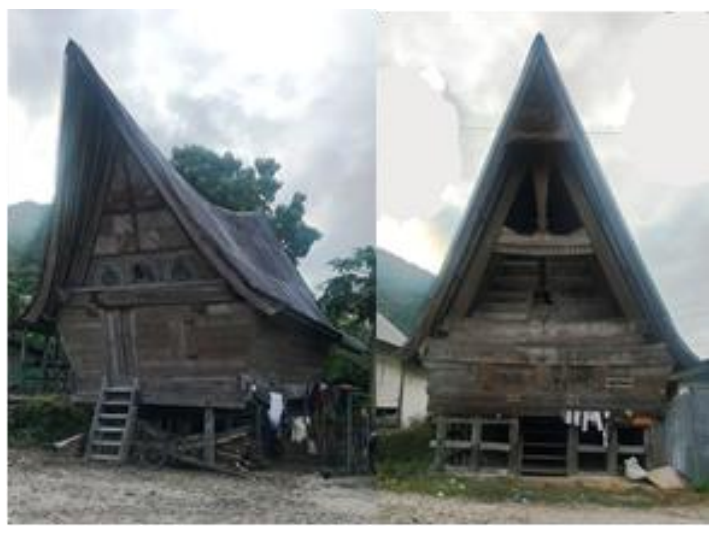

Gambar 10. Fasade Sopo (Lumbung Padi) Huta Bagasan

Perbandingan tasade bangunan menurut seorang Pande, panjang bangunan adalah satu setengah kali lebar bangunan dan tinggi bangunan sama dengan panjang bangunan. Tinggi ujung atap yang satu terkadang berbeda dengan ujung yang lain. Biasanya ujung bagian depan Ruma lebih menjulang ke atas sebagai bentuk penghormatan kepada gunung sebagai orientasi hadap rumah. Tetapi setiap ruma Batak berbeda daerah dengan letak desa berjauhan akan berbeda ciri khas karena sudah beda pula rumpun marganya. Misal Ruma Batak Tobasa akan berbeda dengan Ruma Batak di Pulau Samosir, Ruma Batak Jangga Dolok berbeda dengan Ruma Batak Balige, dan lain-lain. Tiap marga memiliki ciri khas Ruma Batak tersendiri.

\subsubsection{Tiang}

Bangunan di arsitektur ruma batak adalah bangunan kayu, bangunan dengan bahan yang organik. Berbeda dari arsitektur candi yang terbuat dari batu (bahan anorganik) dan tidak tahan gempa, maka tiang ruma batak dirancang untuk tidak disatukan dengan bumi atau tanah, karena dengan cara itu akan tahan gempa. Tiang ruma Batak dapat dilihat pada Gambar 11. Semua tiang bangunan bertumpu pada umpak lepas, sehingga saat gempa bumi bisa bergerak 
tapi tidak merusak konstruksi. Alasan lain, dengan umpak lepas, arsitektur tidak merusak keseimbangan ekologis bumi, sekaligus tidak membiarkan bumi ini dirusak oleh penanaman batu pondasi (Prijotomo, 2008).

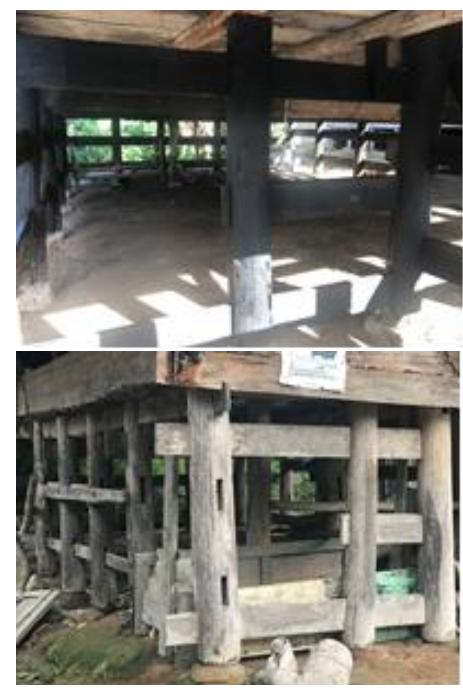

Gambar 11. Tiang Rumah Huta Bagasan

Masih terkait dengan gempa adalah teknik merangkai gelagar di ruma batak, persambungan antar gelagar dilakukan dengan menggunakan konstruksi goyang, sehingga bangunan akan ikut bergoyang sebagai tanggapan atas gerakan gempa. Kalau diperhatikan pada contoh bangunan arsitektur ruma batak diatas, maka semua landasan yang berupa tiang tegak atau balok mendatar di daerah Jangga Dolok diletakkan diatas umpak batu. Hal ini juga memperlihatkan bahwa distribusi beban yang disalurkan oleh tiang tegak maupun mendatar adalah gaya aksial saja. Penggunaan bahan kayu dan pemahaman akan karakter bahan kayu; tinggi tiang kayu; jarak antar tiang; ukuran kayu; pemilihan konstuksi sambungan yang fleksibel meru-pakan keandalan cemerlang struktur ruma batak dalam menanggapi gempa. Dari sisi teknik membangun, proses pembangunan ruma batak menunjukkan bahwa landasan adalah bagian bangunan yang didirikan lebih dahulu, kemudian kerangka lantai dipasang dan kemudian diatasnya didirikan tiang-tiang penyangga struktur atap. Sehingga yang terjadi lebih dahulu adalah kerangka utama bangunan, barulah dipasangkan penutup atap dan penutup badan bangunan (Murtijas, 2016).
Prosesi peletakan batu pertama Ruma adat merupakan sebuah symbol ucapan syukur dalam membangun Ruma Batak Jangga Dolok. Prosesi peletakan batu pertama dilakukan oleh tokoh-tokoh adat dan disaksikan seluruh elemen masyarakat. Pendirian tiang merupakan tahap awal dalam membangun Jabu Bolon. Oleh karena itu sebelum mendirikan tiang diadakan upacara adat dengan tujuan meminta restu dari nenek moyang dan menarik masa guna bergotong-royong mendirikan tiang. Tiang didirikan dengan partisipasi masyarakat sekitar. Pendirian hanya menggunakan alat tradisional berupa palu dan tali dan juga metode tradisional yaitu gotong royong. Semua tiang dan balok diangkat bersama-sama dengan tenaga puluhan orang.

\subsubsection{Atap}

Bangunan di arsitektur nusantara dijadikan sebagai tiruan dari pohon penaung, sehingga bangunan adalah pernaungan, oleh karena itu atap bangunan adalah unsur paling utama dari sebuah bangunan. Tidak mengherankan bila masing-masing anak bangsa berkresi dengan rupa atap yang berbeda termasuk bentuk atap ruma batak. Bagian atap ruma batak merupakan struktur tersendiri yang didirikan diatas lantai/alas bangunan, tiang penahan atap tidak menerus dari tanah. Ruma batak tidak menggunakan kuda-kuda sebagai penahan beban atap. Ruma Batak berarsitektur atap pernaungan yang khas untuk dua musim (penghujan dan panas) dimana dinding bernafas dan aman dari hujan.

Konstruksi Ruma Batak berupa Ruma panggung dengan bahan kayu dengan atap terbuat dari ijuk tanpa menggunakan paku. Bukulan/nok, Urur/rusuk terbuat dari kayu Pokki yang merupakan material utama untuk pembuatan struktur Ruma Batak. Kayu pokki ini banyak bersumber dari Jangga (Desa Jangga Dolok dan Desa Jangga Toruan). Konstruksi atap terdiri dari segitiga penopang utama yang disebut Sitindangi. Sitindangi berjumlah tiga, dimana digunakan sebagai penyangga bukulan atau kayu gelondong yang membentang dari depan hingga belakang. Bukulan/nok ditarik terlebih dahulu sebelum pembebanan, sehingga saat betul-betul pada beban penuh bukulan melentur sesuai beban, hal ini menunjukkan teknologi prestress sudah dikenal saat itu. Di atas bukulan diletakkan urur/usuk. Atap tanpa 
kuda-kuda pada bentang lebar hanya plat bidang dari barisan urur. Bila di atas urur bertumpu pada bukulan, di bagian bawah bertumpu pada tomboman atau listplank yang ditarik dicantolkan ke buaton/murplat bulat oleh ropu hotang/ tali rotan. Konstruksi ruma Batak bisa dilihat pada Gambar 12.

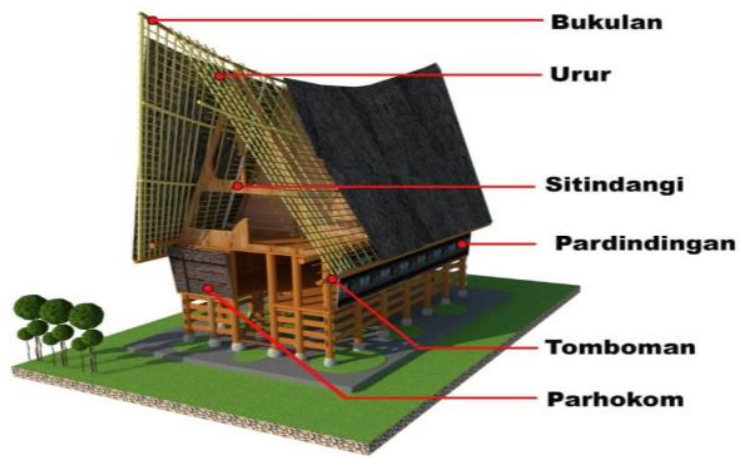

Gambar 12. Konstruksi Ruma Batak

Untuk menopang ijuk sebagai penutup atap, urur diberi alas tikar-tikar yang dibuat dari pelepah pohon aren atau lais. Ijuk sebagai penutup atap memberi kesan menyatu dengan alam pada bangunan Jabu Bolon yang karena bertambahnya umur bangunan atap akan ditumbuhi tumbuhan kecil serta lumut sehingga mengingatkan pemilik Ruma agar merawat Rumanya dengan baik. Sopi-sopi atapnya kaya dengan dekorasi dan ukiran baik dengan finishing cat maupun tanpa cat. Lihat Gambar 13.

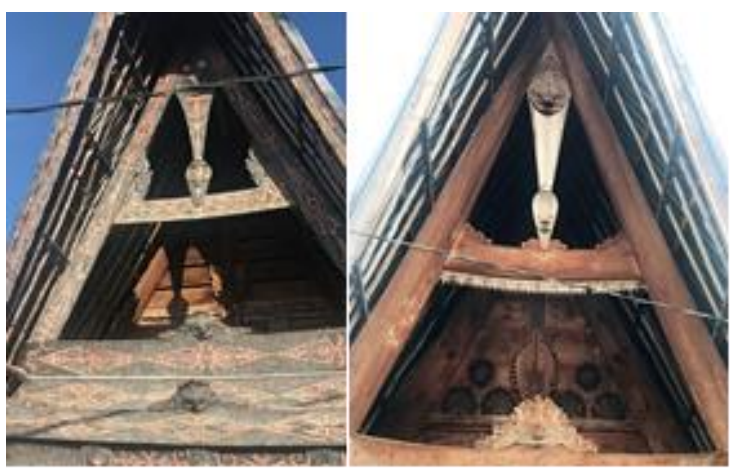

Gambar 13. Ornamen sopi-sopi Huta Bagasan

\subsubsection{Dinding}

Dinding dalam ruma Batak Huta Bagasan diperkaya dengan ornamen dan dekorasi fasade yang bercorak tetumbuhan serta geometrisasinya, serta dengan menggunakan warna yang mencolok dan segar. Dinding pada ruma Batak perbandingan ukurannya kurang signifikan dibandingkan dengan atap yang tinggi menjulang. Rumah bagi orang Batak adalah tempat untuk tidur di malam hari, sedang aktivitas sepanjang hari dari pagi sampai sore lebih dilakukan di luar rumah. Beberapa bagian interior dalam rumah bukan merupakan elemen struktur tetapi diperkaya dengan dekorasi (Hanan, 2011). Dinding sebagai elemen pelingkup yang terdiri dari Parhokom (dinding depan dan belakang) serta perdindingan (dinding samping) yang saling berkaitan dan menumpu pada lantai. Kayu yang digunakan untuk dinding tersebut harus utuh dengan panjang mencapai 8,5 meter, lebar $40 \mathrm{~cm}$, dan tebal $7 \mathrm{~cm}$. Dinding depan pada umumnya dihiasi dengan gorga tuhil (ukir), sedangkan dinding samping pada bagian depan dihiasi gorga tuhil dan dilanjutkan dengan gorga lotik. Dinding ruma Batak Toba bisa dilihat pada Gambar 14.

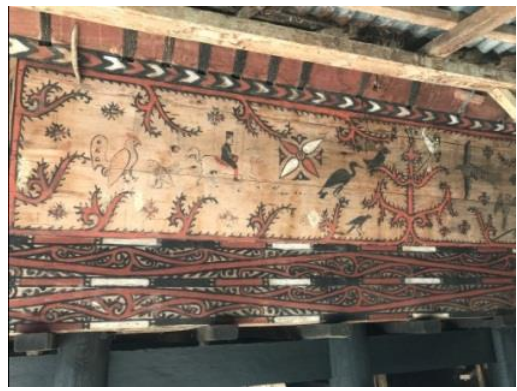

Gambar 14. Dinding luar Ruma Huta Bagasan

\subsubsection{Ornamen}

Ornamen Ruma Batak dilengkapi dengan ukirukiran khas batak (gorga). Fasade Ruma Batak dibentuk dengan ukiran atau lukisan timbul yang berwujud figur-figur yang menggambarkan batara singa yaitu wajah singa yang dipercaya menjadi penjaga Ruma Batak. Ornamen Ruma Batak dibedakan menjadi dua macam, yaitu Ruma dengan ornamen gorga yang berukir dan bercat dan Ruma berornamen polos tanpa cat, seperti terlihat pada Gambar 15. Gorga merupakan elemen penting dalam Ruma Batak, karena gorga merupakan Ruma penanda status sosial. Hanya orang yang mampu secara finansial yang bisa menghiasi Ruma dengan gorga, karena biaya dalam pembuatan gorga yang relatif mahal. Menggorga dilakukan oleh 
para tetua karena dipercaya keahlian ini didapat melalui cara yang "tidak biasa". Maka ketika pengukir atau penggorga akan mengukir sebuah Ruma terlebih dahulu diadakan upacara yang dilakukan oleh penggorga tersebut dan niscaya ilham dari ukiran akan didapat dari upacara tersebut. Konon menurut tetua adat setempat kualitas ukiran gorga bisa menggambarkan watak pemilik Ruma karena erat hubungannya hasil ukiran tersebut dengan cara pemilik memperlakukan penggorga.
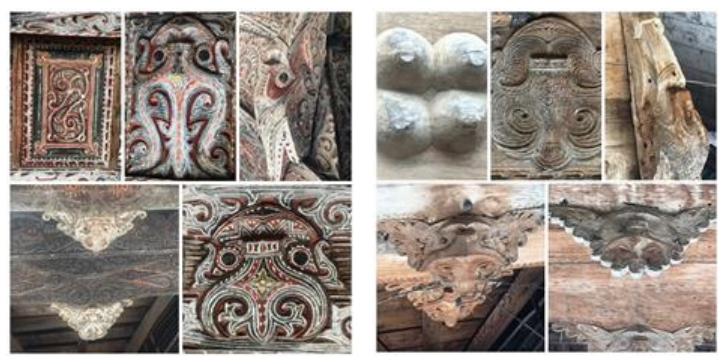

Gambar 15. Ornamen Fasade Gorga bercat \& Ornamen polos

Selain ornamen ukiran khas batak (gorga), ruma Batak juga dilengkapi dengan papan nama yang menunjukkan identitas pemilik rumah (Lihat Gambar 16).

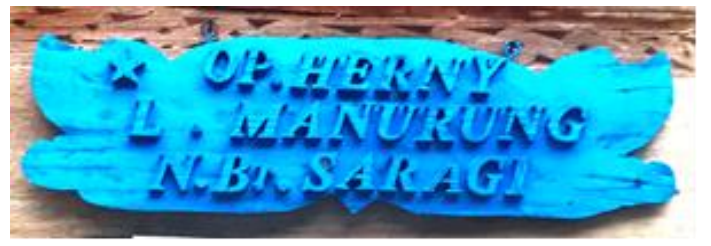

Gambar 16. Papan Nama Ruma Huta Bagasan

\subsubsection{Gorga}

Berdasarkan bentuk dari ornamen dan gambar yang terdapat pada Gorga memiliki sebutan tersendiri, antara lain: 1) Gorga Ipon-ipon; Ipon-ipon berarti gigi dalam Bahasa Indonesia. Ornamen ini terletak ditepi dari Gorga, lebarnya lebih kurang 1-3 cm dipinggir papan, berfungsi sebagai ornamen hiasan tepi yang menarik dan memberikan keindahan serta keharmonisan, 2) Gorga Sitompi; Sitompi adalah gambaran dari perkakas petani yang dikenal dengan nama tompi, yaitu peralatan yang diikatkan dileher kerbau pada saat membajak sawah. Keindahan yang terbentuk dan dimiliki dari ornamen Gorga Sitompi memberikan nilai lebih tinggi dari Gorga Batak yang lain, 3) Gorga Simataniari (Matahari), Simataniari adalah merupakan gambaran matahari, yang dibuat untuk mengingatkan akan peran matahari dalam menerangi dunia, karena perannya sebagai sumber segala kehidupan. Pada umumnya Gorga Simataniari terletak disudut kiri dan kanan rumah, 4) Gorga Desa Naualu (Delapan Penjuru Mata Angin); Gorga yang menggambarkan arah mata angin pada hiasan-hiasannya, hal ini disebabkan mata angin mempunyai kaitan yang sangat erat dengan aktivitas ritual seseorang, 5) Gorga $\mathrm{Si}$ Marogung-ogung (Gong); Ogung (Gong) merupakan benda yang sangat berharga dalam satu keluarga. Kepemilikan Gong pada satu keluarga, menandakan bahwa keluarga tersebut merupakan keluarga terpandang. Pemakaian Gong sangat diperlukan pada kegiatan pesta adat dan upacara-upacara ritual, 6) Gorga Singa; Gorga Singa memberikan gambaran akan sebuah hewan singa yang memiliki kekuatan, kekokohan, kemampuan, dan kewibawaan, 7) Gorga Jorgom; Gorga Jorgom disebut juga sebagai Gorga Ulu Singa, pada umumnya diletakkan di atas pintu masuk ke rumah berbentuk mirip binatang dan manusia, 8) Gorga Boras Pati dan Adop (Tetek); Boras Pati merupakan mahluk sejenis yang menyerupai kadal atau cicak. Kepercayaan adat Batak, apabila Boras Pati menampakkan diri, bertanda tanam-tanaman akan menjadi subur dan panen akan berhasil baik yang menuju kekayaan (hamoraon). Kombinasi Gorga Boras Pati dengan Adop/tetek (susu, tarus), adalah perlambang Hagabeon, Hamoraon sebagai idaman orang Batak, 9) Gorga Ulu Paung; Ulu Paung menggambarkan kegagahan dan kewibawaan. Ulu Paung terletak di puncak Ruma Gorga Batak. Selain memberikan nilai estetika pada rumah, filososfi dari pemasangan Ulu Paung adalah berfungsi untuk melawan begu ladang (setan) yang datang dari luar kampung dan akan memberikan aura negatif pada satu keluarga. Contoh Gorga dapat dilihat pada Gambar 17. 


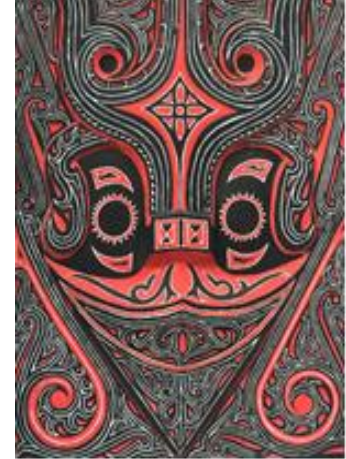

Gambar 17. Gorga Batak

\subsubsection{Penggunaan Warna}

Budaya Batak sarat dengan simbolisasi yang mengandung makna yang sangat dalam diwujudkan dalam bentuk fisik maupun non fisik dan dalam bentuk ukiran, gambar maupun warna yang khusus. Hal ini dapat dilihat dari penggunaan warna dalam gorga. Begitu juga di Huta Bagasan Desa Jangga Dolok, disamping mempunyai daya tarik sebagai unsur keindahan, warna juga mengandung makna dan simbolisasi. Pengecatan gorga dengan menggunakan bahan alami untuk membuat larutan pewarna yang kuat dan tahan lama dan menciptakan warna yang memiliki arti sebagai karakter dan symbol dalam kehidupan orang Batak Toba. Warna-warna tersebut yaitu Narara atau warna merah dari batu hula sebagai lambang kecerdasan dan berwawasan luas sehingga lahir kebijaksanaan. Nabontar atau warna putih dari Tanah Buro sebagai lambing kejujuran yang tulus sehingga lahir kesucian. Nabirong atau warna hitam dari jamur sebagai lambing kewibawaan yang melahirkan kepemimpinan.

\subsubsection{Kehidupan Sosial Budaya}

Dalam usaha untuk mencapai integrasi antara elemen-elemen fisik suatu kawasan, perlu pula memahami tentang budaya yang menjadi ciri khas dari kawasan tersebut, sehingga ruang akan bermakna sebagai tempat (place) bagi masyarakat yang menggunakannya (Rapoport,1969). Tortor atau disebut juga manortor merupakan tarian seremonial khas Batak yang disajikan dengan musik gondang (Lihat Gambar 18). Meski berwujud tarian, tortor memiliki makna tersendiri karena gerakan-gerakannya adalah media komunikasi dimana dengan gerakan yang disajikan akan terjadi respon dari partisipan upacara.

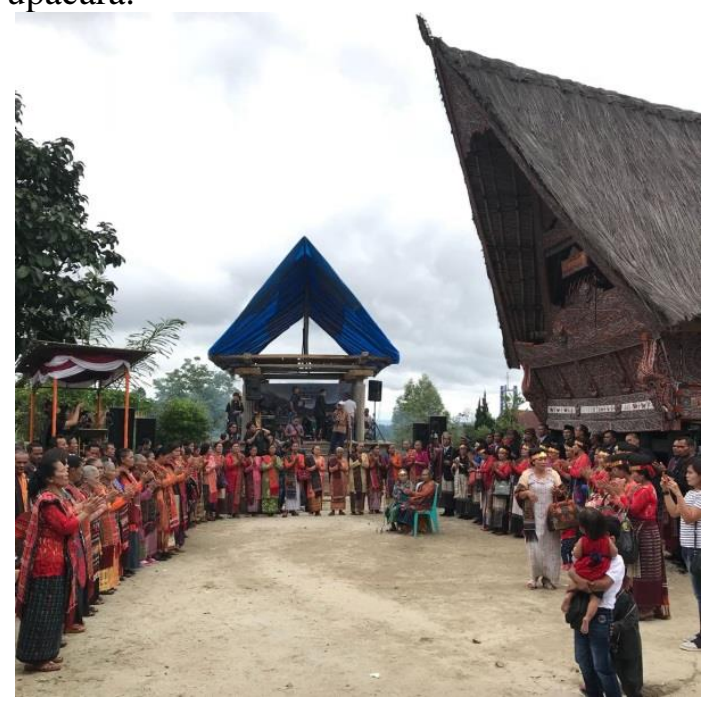

Gambar 18. Tarian Tortor

Tarian ini dipakai di berbagai upacara adat seperti Mongolai (Upacara Adat pernikahan) dan Marojungolu (Upacara Adat kematian). Dalam melakukan tarian tortor masyarakat Batak menngunakan ulos yaitu kain adat batak yang dibuat dengan cara ditenun.

\section{KESIMPULAN}

Dari hal tersebut di atas maka dapat diambil kesimpulan akhir bahwa aspek-aspek yang berpengaruh terhadap arsitektur Ruma adat di Huta Bagasan Jangga Dolok secara tidak langsung membentuk sebuah identitas yang khas di kawasan tersebut. Secara makro tipologi Ruma Batak Toba sangat kentara dan memiliki ciri tertentu yang mudah dikenali orang. Simbolisasi Ruma Batak Toba di Huta Bagasan Jangga Dolok dibentuk dan dipengaruhi oleh komponen-komponen: 1) Elemen fisik, meliputi tipologi, fasade, atap, ornamen, warna ruma batak sebagai komponen utama. Ruma Batak Toba mudah dikenali secara fisik, dimulai dari fasade bangunan yang khas dengan model atap yang melengkung pada bukulan dan menghadap ke arah gunung; 2) Elemen non fisik, meliputi kebudayaan masyarakat Batak dan kehidupan sosial budaya sebagai komponen penunjang. Masyarakat Batak Toba di Jangga Dolok umumnya memiliki agama Kristen Protestan dengan adat yang cukup kuat dan pada waktu tertentu 
mengadakan upacara ritual di Desa Jangga Dolok. Pada perkampungan Batak terdapat rumah tinggal dan lumbung padi yang terletak pada sisi yang berbeda dan berhadap-hadapan, diyakini orientasi ruma batak harus menghadap ke arah gunung sebagai bentuk penghormatan kepada gunung sebagai lambang kekuatan alam yang dihormati oleh masyarakat Batak.

\section{REFERENSI}

Hanan \& Meisyara. 2017. Lesson Learned from the Transformation Process of Toba Batak Villages. Journal of Comparative Cultural Studies in Architecture, Vol.10 (2017), p. $35-41$

Hanan \& Wonorahardjo. 2012. The Architecture of Batak Toba: An Expression of Living Harmoniously. Journal of Environmental Design and Planning, Vol.7 (2012) Faculty of Architecture, Chulalongkorn University, p. 11-22.

Hanan, Himasari. (2011). A House is a Figure between the Earth and the Sky Case Study: Batak Toba House in Samosir Island. In: Jurnal Ruas, Vol 9, No 2 (2011), Jurusan Arsitektur, Universitas Brawijaya.

Mangunwijaya, Y.B. 1995. Wastu Citra, Pengantar ke Ilmu Budaya Bentuk Arsitektur Sendi-sendi Filsafatnya Beserta Contoh-contoh Praktis. Jakarta: PT Gramedia.

Muhadjir, Noeng, 1996, Metodologi Penelitian Kualitatif, Rake Sarasin, Yogyakarta.

Prijotomo, Josef. 2008. Pasang Surut Arsitektur Indonesia. Surabaya: Wastu Lanas Grafika.

Prijotomo, Josef. 2018. Prijotomo membenahi Arsitektur Nusantara. Surabaya: Wastu Lanas Grafika.

Rapoport, Amos. 1996. House Form and Culture. Prentice-Hall, Inc. Englewood Cliffs, New York.

Rumah Asuh. 2018. The Rise Of Jangga Dolok. Katalog Restorasi Ruma Adat.

Shirvani, Hamid, 1984, The Urban Design Process, Van Nostrand Reinhold Company, New York.

Soeroto, Myrtha. 2002. Dari Arsitektur Tradisional Menuju Arsitektur Indonesia. Penerbit Ghalia Indonesia, Bogor.
Sulistijowati, Murtijas. 2016. Struktur Di Arsitektur Nusantara, Prosiding Temu Ilmiah Tahun 2016. IPLBI.

https://tanobatak.wordpress.com/2007/06/07/r uma-gorga-batak/ 